\title{
158. 蛍光ガラスによる放射照度計
}

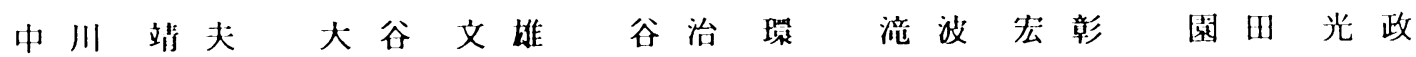

( 埼玉 大学工学 部)

荒术漫和池下萧光

(埼玉工業大学)（コスモ技研(陎)）

1.まえがき リソグラフィや C V D による成膜などには、大電力の水銀ランプなどによる 高強度の紫外放射が用いられている。これら操作は密閉容器内で放射源を至近距離に設置して行う ために、放射照度测定の受光器は極薄形（例えば厚さ $2 \mathrm{~mm}$ ) で、大入射角で $\cos \theta$ に近い斜入射

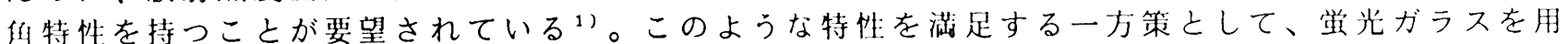
いた放射照度計を検討したので発表したい。

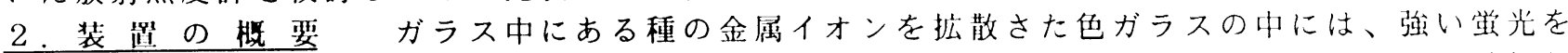
発するものがある(例えばある種の遮断形の光学フィルタ)。このようなガラスの表面に紫外放射

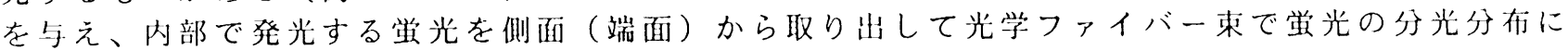
合せたバンドバスフィルタを付けた、フォトダイオードなどへ導くようにすると、薄形で大入射角 で使用できる满造が達成できる。また、材料を選定すれば高い紫外放射にたいする耐久性も期待で きる。図 1 このようなものの構造の一例を示す。

3.出本们な特性 7 種の监光ガラス（東芝，保谷製色ガラスフィルタ）を試料として紫外 $254 \mathrm{~nm}, 365 \mathrm{~nm}$ 放射についてこのような目的に対する特性を検討した。(1) 励起光と䖝光の并係

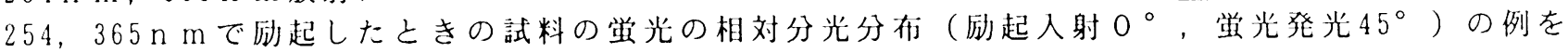
困 2 に示す。この例では、波長500 $\mathrm{nm}$ 以上では励起波長による営光の分光分布の変動は少ない。

(2) 斜入射们特性 $254,365 \mathrm{~nm}$ の入射に対する例を図 3 に示す。斜入射角特性は一般に良好で $80^{\circ}$ 程度まで十分使用できることが分る（端面から光ファイバー束で鸴光を取り出した状態で）。

(3) 放射䃇の可視光の洩れ込み フォトダイオードに組合わせるバンドパスフィルタを500〜600 $\mathrm{nm}$ とすると水銀発光の546,589 n m 放射の洩れ込みがあり得るので、その程度を低压水銀ランプ

( GL - 10) でチエックした。結果を図 4 に示す。

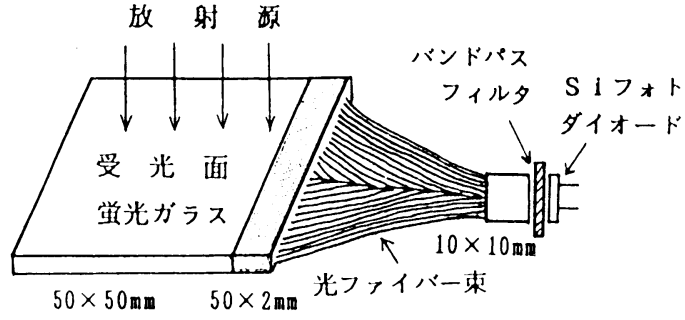

圀1 放射照度計の满成図

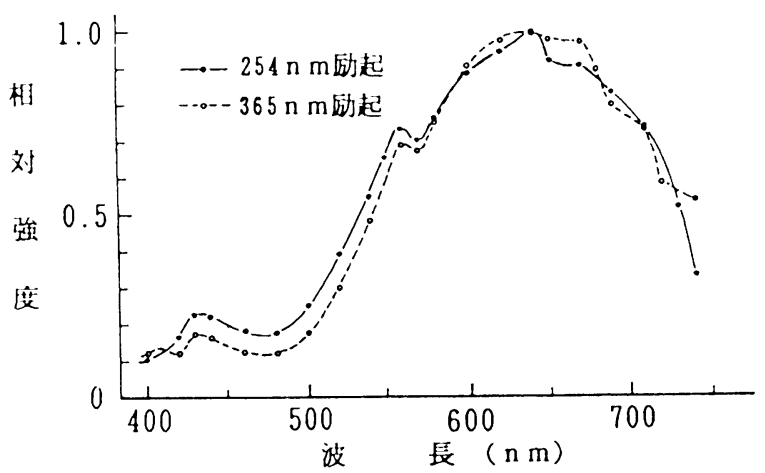

図2 鉴光発光の分光分布の例

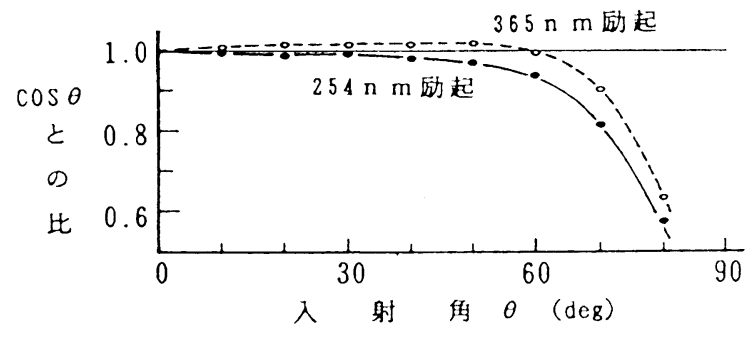

図3 斜め入射角特性

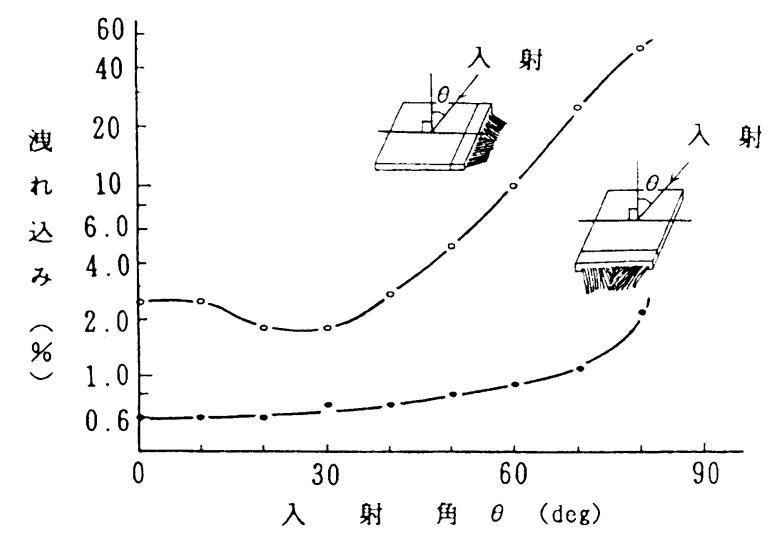

因4546 n m 放射の波れ込み

文 献 1) 照明学会 紫外放射の放射照度测定方法特別研究委員会報告書第 1 分冊平成6年 3 月

Irradiance Meters of Fluorescent Glass

Yasuo Nakagawa, Fumio Ohtani, Tamaki Yaji, Hiroaki Takinami, Mitumasa Sonoda, Yosikazu Araki, and Kanemitu Ikesita. 